\title{
Elements of reflection on education for sustainable development 30 years from the Bruntland Report
}

\author{
Joanna Kostecka1*, Maria Cyrankowska ${ }^{2}$, Agnieszka Podolak, \\ Brygida Kowalska' \\ ${ }^{1}$ Department of Biological Basis of Agriculture and Environmental Education, Faculty of Biology and Agriculture, \\ University of Rzeszow, ul. Ćwiklińskiej 1, 35-601 Rzeszow, Poland \\ ${ }^{2}$ Foreign Languages Centre, University of Rzeszow, Poland \\ *jkosteck@ur.edu.pl•ORCID 0000-0003-4247-3685
}

\begin{abstract}
The aim of the study was to learn about young people's judgements on sustainable development and environmental protection depending on their school profile and education. The presentation of their opinions was considered important for assessing the state of sustainable development 30 years after the publication of the Bruntland Report. The perception of the phenomenon of "ecological violence" and the opinions regarding the directions of actions to combat it were also identified. In the authors' opinion, this concept should be included in the ethical foundations of human behaviour in the 21st century. The research was conducted in 2017 with students of the Faculties of Biology and Agriculture and of Pedagogy at the University of Rzeszow and students of the Faculty of Management at the Rzeszow University of Technology. In order to achieve the study goals, a diagnostic survey using a questionnaire was used. The results indicate that education in sustainable development is not carried out equally in all university institutions. It is often underestimated, although the media clearly emphasise the need to solve current problems in such a way as to minimise the negative effects of sustainability-related decisions made on the economic, social and ecological dimensions of life. All these dimensions are equally important for the welfare of the human species. The results of the study may indicate the directions of activities necessary in education for the sustainable development in the 21st century.

In search of effective educational and implementation activities for broadly defined sustainable development, it is also worth presenting, examining and refining the term "ecological violence". This article touches on the above issue and is a preliminary consideration in this respect. The authors hope that it will lead them and potential readers to a deeper analysis of the possible meaning of the term "violence" also in relation to environmental resources. The presented research results are regarded as preliminary findings for a deeper analysis of this issue in the future.
\end{abstract}

\section{Keywords}

education, sustainable development, ecological violence 


\section{Introduction}

The condition of Earth's ecosystems in the 21st century is perceived by many authors as a threat to the safe functioning of the global human population and its broadly understood well-being (Guide to... 2015, Popkiewicz 2015, Wilson 2016). The situation requires rapid and effective actions that will allow us, for example, to halt the decline of biodiversity and stop the degradation of ecosystem services (Kostecka 2009, 2013a, Cavender-Bares et al. 2015, Knutelski 2018). For this to happen Man, who is the main perpetrator of the broadly understood degradation of ecosystems must change not only the way of acting, but above all the way of thinking. Human ethics is of great importance for a new human attitude. As a general reference point for the evaluation and regulation of behaviour, ethics, being the general moral norms recognized at specific times by separate social communities, integrates people around values essential for the efficient and strategically well organised social functioning.

It seems that the 21st century must be a time of deepened ethical awareness of ecology. The survival of the species Homo sapiens requires a morally rooted, deep acceptance and universal compliance with the principles of prevention of losses in the environment, and when they cannot be prevented, what is needed is the acceptance of the broadly understood natural restitution and slowing down the further transformation of natural resources (Kostecka 2010, 2013b), for example biodiversity resources of insects (bees and other pollinators, species favourable to plant protection, waste recirculation in nature) and other representatives of invertebrate and vertebrate fauna, flora and microorganisms. On the other hand, it is also necessary to introduce ethical standards of conduct that take into account basic human needs to ensure our well-being, which is increasingly difficult to achieve with the general publics' lack of awareness of the importance of ecosystem services (Kostecka et al. 2013).
The aim of the study was to learn of knowledge that young people currently have on sustainable development and environmental protection, depending on the school profile and education they receive. Presentation of these selected opinions was considered important for building sustainable development 30 years after the publication of the Bruntland Report. The perception of the phenomenon of "ecological violence" and the opinions on the directions of actions to fight it were also analysed. This research presents preliminary findings in this area.

\section{Material and research method}

On the basis of our long-term reflections and studies of education for sustainable development, the definition of the term "ecological violence" was adopted as "actions carried out by people violating human and nature rights to safe functioning, causing gradual, often irreversible damages to the environment". The research was conducted in 2017 among students of the University of Rzeszow at the Faculty of Biology and Agriculture in addition to Pedagogy, and students of the Rzeszow University of Technology at the Faculty of Management. A total of 150 people participated in the study (50 students from the 4 th and 5 th year from the above Faculties, including 98 women). In order to achieve the assumed goals, the method of a diagnostic survey using a questionnaire was used. This included 22 closed questions verifying the research assumptions - (Table 1), to which the surveyed students anonymously provided their answers. The publication does not include a questionnaire, but the answers to the closed questions are usually supplied when presenting the results of the survey. The following acronyms were adopted: for the students of Environmental Protection at the Faculty of Biology and Agriculture of the University of Agriculture "EP", for the students of UR at the Pedagogy Faculty, Social Prevention and Resocialization "PSaR", and for the students of the Rzeszow 
Table 1. Adopted research assumptions

\begin{tabular}{|c|c|}
\hline Assumptions & Verifying questions \\
\hline $\begin{array}{l}\text { 1. Respondents understand the basic } \\
\text { terms in the field of sustainable } \\
\text { development and environmental } \\
\text { protection }\end{array}$ & $\begin{array}{l}\text { How do you understand the following terms } \\
\text { (the answers are supplied in the results in Table } 2^{\star} \text { ) } \\
\text { 1. Sustainable development } \\
\text { 2. Environmental protection } \\
\text { 3. Ecology } \\
\text { 4. Biodiversity }\end{array}$ \\
\hline $\begin{array}{l}\text { 2. Respondents recognize violence in } \\
\text { their surrounding }\end{array}$ & $\begin{array}{l}\text { 5. Have you ever encountered violence or experienced it in your environment? } \\
\text { 6. Which form of violence is the most common? }\end{array}$ \\
\hline $\begin{array}{l}\text { 3. Respondents recognize the term } \\
\text { "ecological violence" }\end{array}$ & $\begin{array}{l}\text { 7. Is there a concept of "ecological violence"? } \\
\text { 8. Choose the most appropriate definition of the term "ecological violence" } \\
\text { 9. What determines ecological violence? }\end{array}$ \\
\hline 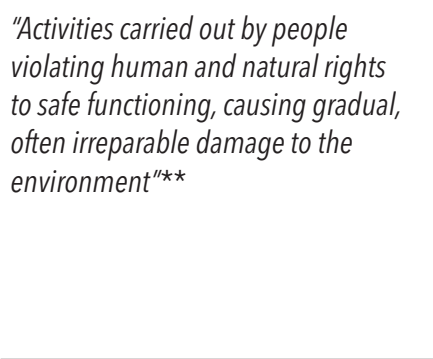 & $\begin{array}{l}\text { 10. What causes a society / citizen to commit ecological violence? } \\
\text { 11. Which phenomena carry environmental threats on a large scale? } \\
\text { 12. Which form of "ecological violence" is the most common? } \\
\text { 13. Do you think that with a limited budget, you can burn rubbish in your home } \\
\text { furnace? } \\
\text { 14. Have you ever thrown litter (paper etc.) into the streets because there was no } \\
\text { litter bin in sight? } \\
\text { 15. Do you think that deliberate product aging is an example of environmental } \\
\text { violence? }\end{array}$ \\
\hline $\begin{array}{l}\text { 4. Respondents see the need for } \\
\text { resocialisation of people who commit } \\
\text { "ecological violence" }\end{array}$ & $\begin{array}{l}\text { 16. Do you think that the term "ecological violence" should appear in the Polish } \\
\text { law? } \\
\text { 17. Can rehabilitation refer to the relationship between man and nature? } \\
\text { 18. What is the most effective tool in the social rehabilitation of society? }\end{array}$ \\
\hline $\begin{array}{l}\text { 5. Respondents see the need for } \\
\text { responsible action in the environment }\end{array}$ & $\begin{array}{l}\text { 19. Who is the most responsible for the state of the environment? } \\
\text { 20. Would you like to make the punishment more severe for the devastation of the } \\
\text { environment, fauna, flora and fungi? } \\
\text { 21. Do you think that the university has sufficiently presented you with the } \\
\text { problems of the functioning of the environment? } \\
\text { 22. Do you think that urgent education for sustainable development will contribute } \\
\text { to the improvement of the quality of human life? }\end{array}$ \\
\hline
\end{tabular}

* Similarly, the answers to further questions suggested in the survey are available with the further results presented

** Authors definition of the adopted term

University of Technology, Logistics "LOG”. The collected material was analysed and described. Survey results were evaluated using a Microsoft Excel 2010 spreadsheet and presented as percentages in the tables and graphs.

\section{Findings}

\subsection{Respondents understand the basic terms of sustainable development and environmental protection}

The results of this part of the study indicate the influence of the field of education on the selection of the terms mentioned. Ninety percent of students of the Faculty of Biology and Agriculture (EP) indicated the broadest explanation of sustainable development, consistent with the Bruntland definition. 
Achieving a high technological level while maintaining the balance in the environment (with the first emphasis on technical development, without highlighting social aspects) was chosen by $40 \%$ of students of Social Prevention and Resocialisation (PSaR) and $50 \%$ of Logistics students (LOG) (Table 2).

A large part (40\%) of the LOG students and $60 \%$ of the PSaR students did not correctly choose the term "environmental protection", probably not quite understanding its tasks. Most EP students (86\%) pointed to the correct answer (,actions leading to the preservation or restoration of the natural balance, necessary to provide the contemporary and future generations with decent living conditions"). They also understood the concept of ecology (80\%), when the other respondents knew them less well (respectively - 50\% of PSaR students and $45 \%$ of LOG students gave the correct answer). The choice of answers in terms of determining the term biodiversity was similar. The students of EP ( $83 \%)$ gave the most correct answers, followed by PSaR students $(43 \%)$ and LOG students $(40 \%$ of correct answers).

\subsection{Respondents recognize violence in their surrounding}

The analysis shows that about half of the surveyed students of all Faculties pointed to the occurrence of violence in the environment, witnessing or experiencing it occasionally (Fig. 1). The answers of the students of Environmental Protection were similar to those of the students of Social Prevention and Resocialization. The least experience with violence was declared by the students of the Logistics Faculty, who were not sure or never witnessed violence in their surroundings.

The respondents considered psychological violence as the most common form of violence used by mothers and children,

Table 2. Understanding the concept of sustainable development

\begin{tabular}{|c|c|c|c|}
\hline Respondents' answers [\%] & EP & PSaR & LOG \\
\hline $\begin{array}{l}\text { A process aimed at achieving a high technological level while maintaining the balance } \\
\text { in the environment }\end{array}$ & 10 & 40 & 50 \\
\hline $\begin{array}{l}\text { A process aimed at improving the living conditions and health of the society by increasing } \\
\text { access to goods and services }\end{array}$ & - & 14 & 10 \\
\hline $\begin{array}{l}\text { A process that satisfies the development needs of present generations while maintaining } \\
\text { the possibility of satisfying them for the next generations* }\end{array}$ & 90 & 46 & 40 \\
\hline
\end{tabular}

* The broadest answer, consistent with the Bruntland definition

Source: own research

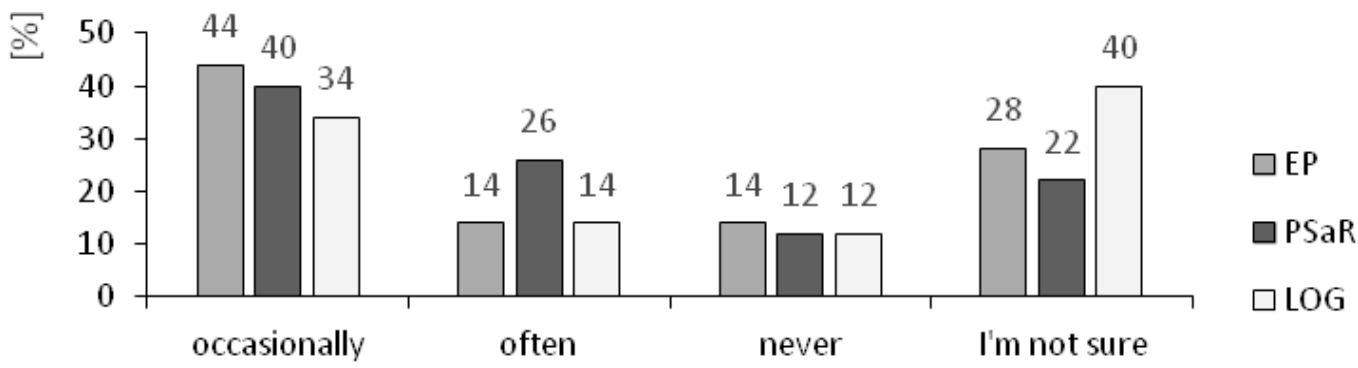

[answers]

Fig. 1. Noticing or experiencing violence in your environment [\%]

Source: own research 
physical violence by fathers and sexual violence by other people (Table 3 ).

\subsection{Respondents recognize ecological violence}

When asked: "Is there a concept of ecological violence" even the students of EP replied only: heard it somewhere $(42 \%)$ and never heard it (42\%). The existence of the term was acknowledged by only $12 \%$ of them. Over $60 \%$ of respondents studying Logistics and $46 \%$ of respondents of SPaR admitted that they had never heard of the concept of "ecological violence"(Fig. 2).

The respondents intuitively chose the definition of ecological violence adopted by the authors of the study („human actions violating human and nature rights to safe functioning, causing gradual, often irreversible damage to the environment") 96\% students of PSS, 74\% of PSaR and $72 \%$ of LOG students.

Over $60 \%$ of the surveyed students of Environmental Protection have noticed that buying too many goods and services can be related to ecological violence (understood as straining the ability of ecosystems to produce). The same answer was chosen by only $8 \%$ of PSaR students and $18 \%$ of LOG students (Fig. 3). Other examples were evenly selected: most often - no waste sorting; destruction of flora and fauna and air pollution by the local factory.

Most respondents blamed low environmental awareness and low public involvement in pro-ecological activities for the main reason for committing ecological violence. It was also considered important to downplay the ecological problems and the lack of stricter legal provisions in the field of environmental protection (Table 4).

The main environmental hazards were: the exploitation of non-renewable resources $(43 \%$ - EP, 31\% - PSaR, 26\% LOG), destruction of biodiversity (32LOG, 30\% - PSaR, 29\% - EP), deforestation (45\% - EP, 24\% - LOG, 19\% - PSaR) and ozone hole (35\% - PSaR, 31\% - LOG, 20\% EP) (Table 5). It may be assumed that the respondents would see the importance of ecological violence in a similar way, recognizing it in these areas.

The most frequently mentioned phenomena of ecological violence were the linked actions of individuals (38\%) and the functioning of enterprises in relation to biodiversity (37\%). The entrepreneurs' violence

Table 3. The most common forms of violence and perpetrators

\begin{tabular}{|c|c|c|c|c|}
\hline Respondents' answers [\%] ${ }^{\star}$ & Psychological & Physical & Sexual & Other \\
\hline Father & 12 & 27 & 14 & - \\
\hline Mother & 30 & 13 & 8 & - \\
\hline Child & 30 & 15 & 3 & neglect \\
\hline Another adult & 15 & 18 & 27 & - \\
\hline
\end{tabular}

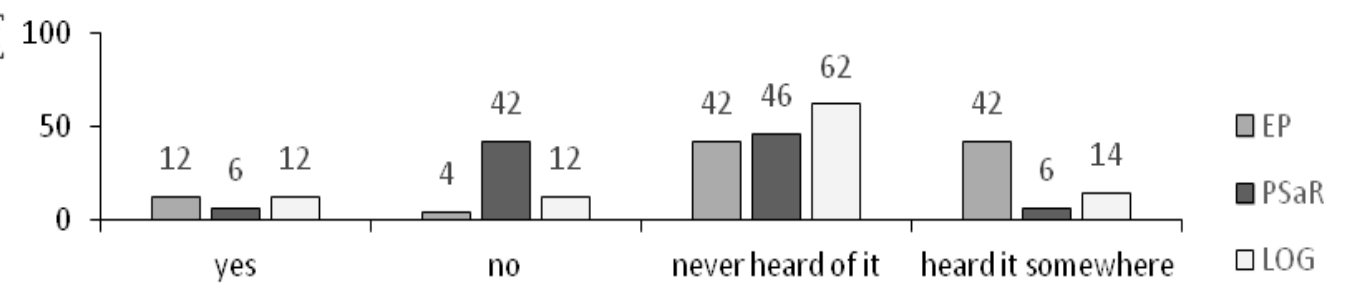

Fig. 2. The existence of the term "ecological violence"[\%] 


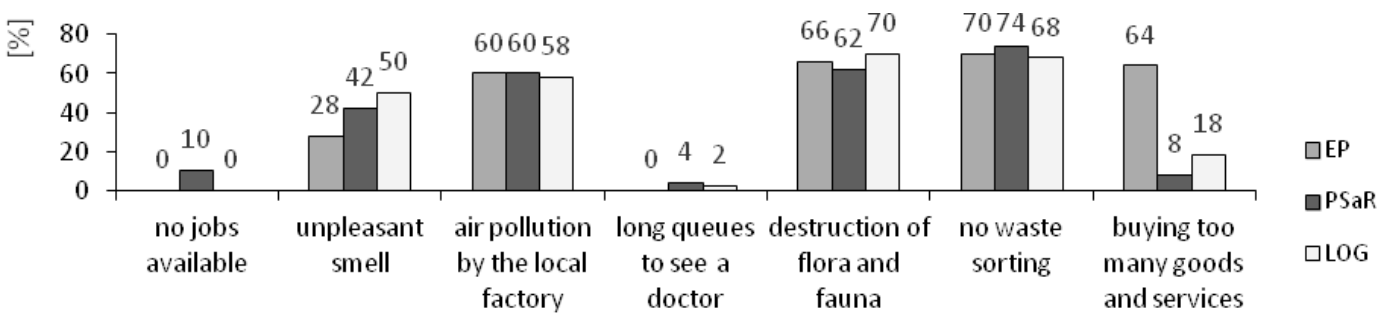

[answers]

Fig. 3. Selecting examples of ecological violence $\left[\%{ }^{*}\right]$, "multiple choice

Source: own research

Table 4. Causes of the use of ecological violence (by the public / individuals)

\begin{tabular}{lccc}
\hline \multicolumn{1}{c}{ Answers of respondents [\%] } & EP & PSaR & LOG \\
\hline Low awareness and little involved in pro-ecological activities & 37 & 26 & 30 \\
\hline No stricter legal regulations in the field of environmental protection & 28 & 18 & 11 \\
\hline $\begin{array}{l}\text { Insufficient activity of local authorities in the field of environmental } \\
\text { protection }\end{array}$ & 14 & 15 & 17 \\
\hline Underestimating ecological problems & 32 & 22 & 27 \\
\hline $\begin{array}{l}\text { Ido not know because I do not really understand what this phenomenon } \\
\text { is about }\end{array}$ & - & 14 & 8 \\
\hline
\end{tabular}

Source: own research

Table 5. Phenomena threatening the environment on a large scale

\begin{tabular}{lccc}
\hline \multicolumn{1}{c}{ Answers of respondents [\%] ${ }^{*}$} & EP & PSaR & LOG \\
\hline Alcoholism & - & 7 & 5 \\
\hline Cancers & 1 & 3 & 1 \\
\hline Destruction of biodiversity & 29 & 30 & 32 \\
\hline Exploitation of non-renewable resources & 43 & 31 & 26 \\
\hline Deforestation & 45 & 19 & 24 \\
\hline The hole in the ozone layer & 20 & 35 & 31 \\
\hline Eutrophication of water resources & 16 & 16 & 15 \\
\hline Acid precipitation & 7 & 9 & 11 \\
\hline Other important threats according to you & 7 & 14 & 16 \\
\hline
\end{tabular}

* Percentage in relation to the number of all the respondents

Source: own research

in relation to ecosystems was also often noticed (35\%). Ecological violence was least frequently associated with the relation of an individual towards other people in ecosystems (Table 6). The latter seems to have been unduly underestimated and neglected because anthropopressure in the sphere of ecosystems (which can also be understood as ecological violence) usually ends with negative pressure on people.
In Poland, the state of air, both in cities and in the countryside, is getting worse during autumn and winter. Those who are considered guilty are so-called small heat users, that is, all citizens heating their homes individually. Very often and for various reasons, they burn waste in domestic furnaces. The effects of such acts are very dangerous. Even with a limited budget, the vast majority believed that they were not 
Table 6. The most common forms of ecological violence and its perpetrators

\begin{tabular}{lccc}
\hline Answers of respondents $[\% *]$ & Towards biodiversity & Towards ecosystems & $\begin{array}{c}\text { Towards people } \\
\text { in ecosystems }\end{array}$ \\
\hline The functioning of enterprises & 37 & 35 & 18 \\
\hline Individuals & 38 & 22 & 9 \\
\hline State & 27 & 29 & 26 \\
\hline
\end{tabular}

* Percentage in relation to the number of all the respondents Source: own research

allowed to incinerate household waste. The sentence "I really do not have a way out" was represented only by relatively few students of PSaR (20\%) and LOG (22\%). Only few people in the same groups of respondents would feel excused for commiting this environmental crime (Table 7). Likewise, students of PSaR and LOG (Table 8) more often admitted dropping litter.

Over $70 \%$ of the surveyed EP students believed that deliberate aging of the product is a threat to the environment, because there is more and more waste and less and less resources. This view also had many followers among the other respondents. Almost all respondents knew what deliberate aging of the product was (Table 9).

Respondents were rather unanimous in saying that Man does more harm to nature
(100\% of EP students, $90 \%$ of PSaR students and $84 \%$ LOG students) than nature to Man (this answer was chosen by $10 \%$ of PSaR students and $14 \%$ of LOG students). The idea that humans and nature have nothing to do with each other was only supported by $2 \%$ of respondents (Table 10).

\subsection{Respondents see the need to re-socialize people using ecological violence}

Seventy six percent of EP students believed that the term "ecological violence" should appear in Polish law. This opinion was also given by $42 \%$ of SPaR students and $32 \%$ of students in Logistics. Twenty four percent of EP students and $28 \%$ of SPaR students had no opinion on this matter. Thirty percent of the latter clearly said "no" to the question whether ecological violence should occur in

Table 7. Assent for burning garbage in a domestic furnace

\begin{tabular}{lccc}
\hline \multicolumn{1}{c}{ Answers of respondents [\%] } & EP & PSaR & LOG \\
\hline Yes, of course - I can burn garbage & - & 2 & 2 \\
\hline I do not have any other option & 4 & 20 & 22 \\
\hline Absolutely not & 96 & 78 & 76 \\
\hline
\end{tabular}

Source: own research

Table 8. Dropping litter when there is no bin available

\begin{tabular}{lccc}
\hline \multicolumn{1}{c}{ Answers of respondents [\%] } & EP & PSaR & LOG \\
\hline Yes, often & - & 14 & 6 \\
\hline Yes, but sporadically & 44 & 48 & 42 \\
\hline I do not remember, I do not pay attention to it & 10 & - & 22 \\
\hline Probably not & 34 & 14 & 20 \\
\hline Never & 12 & 24 & 10 \\
\hline
\end{tabular}


Table 9. Deliberate aging of the product as an example of environmental violence

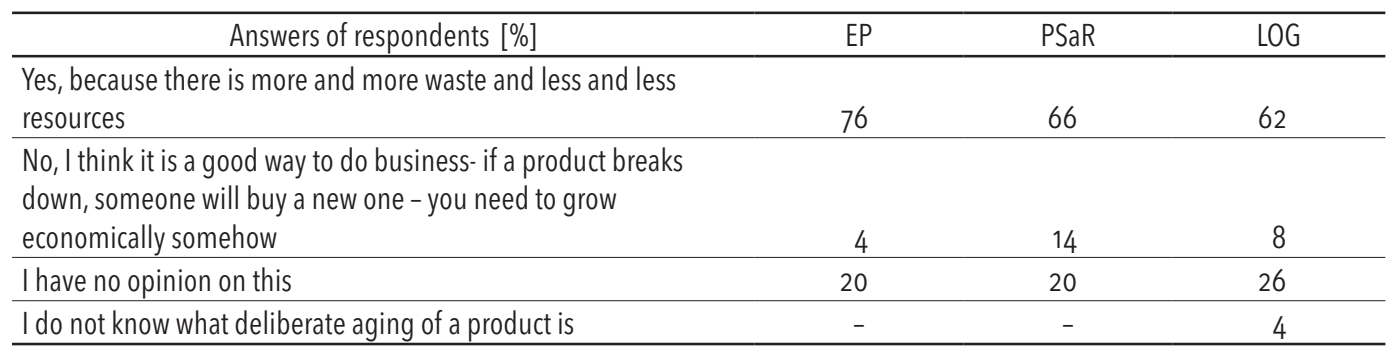

Source: own research

Table 10. Man and nature - coexistence

\begin{tabular}{lccc}
\hline \multicolumn{1}{c}{ Answers of respondents [\%] } & EP & PSaR & LOG \\
\hline Man does more harm to nature & 100 & 90 & 84 \\
\hline Nature does more harm to man & - & 10 & 14 \\
\hline Humans and nature have nothing to do with each other & - & - & 2 \\
\hline
\end{tabular}

Source: own research

Polish law. Fourteen percent of the Logistics Faculty students marked "no" and 54\% had no opinion.

The majority of the surveyed students of all faculties were of the opinion that social rehabilitation may also refer to the problem of human relation to nature, but some PSaR students (24\%) and LOG students (30\%) had doubts about it (Fig. 4).

Among the proposals of activities that will be most effective in social rehabilitation of society, the students surveyed most often chose: "The creation of a television programme free from lies, showing the true direction in which the world is going."Then they chose: "Increasing the number of educational programs building ecological awareness", and "Distributing free books in the community regarding ecological problems and the current state of the environment containing a proposal to solve the problem". The least number of votes received the answer: "Mandatory introduction of the course of Environmental Protection" in the programs of all subject areas (Table 11).

It seems that the introduction and functioning of the concept of ecological violence in everyday language can be of great emotional significance and, consequently, block the undertaking of environmentally burdensome activities in the case of some citizens. The term "violence", which is clearly negative, will allow people to realize the importance of the problem, and the reference to emotions will make the problem remain longer in the memory. We learn faster and remember the content associated with emotions.

Summing up, the data collected in this part of the questionnaire can suggest that a vast majority of the surveyed students are aware that Man harms nature and should undergo rehabilitation in this field through effective education.

\subsection{Respondents see the need for responsible activity in the environment}

All students in the field of Environmental Protection (100\%) were aware that each of us was responsible for the state of the environment, and some also attributed this responsibility to environmental organizations (16\%) and state organizations (6\%) (Fig. 5). Moreover, almost 90\% of them admitted that severe punishment should be considered for the devastation of the 


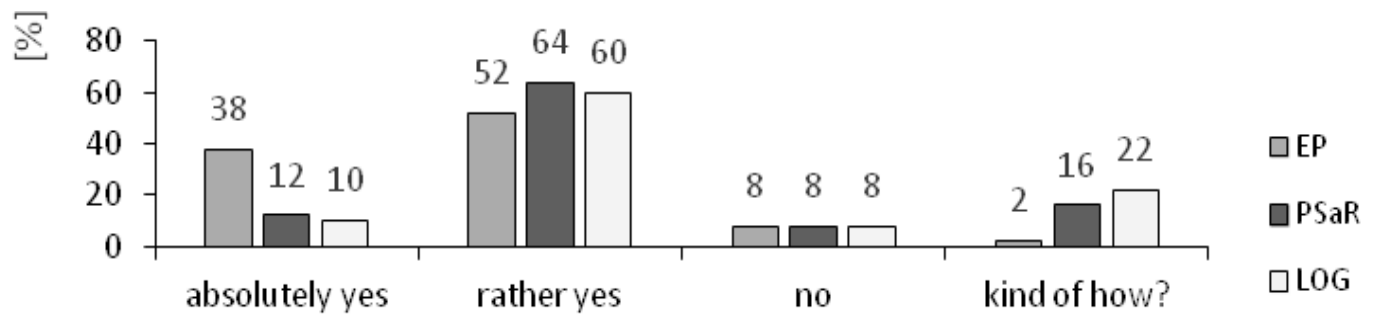

[answers]

Fig. 4. Can rehabilitation relate to the relationship between man and nature [\%]

Source: own research

Table 11. Most effective actions in the social rehabilitation of society

\begin{tabular}{lccc}
\hline \multicolumn{1}{c}{ Answers of respondents [\%]* } & EP & PSaR & LOG \\
\hline Tightening legal provisions within the scope of environmental protection & 28 & 24 & 20 \\
\hline Increasing the number of educational programs building ecological awareness & 52 & 44 & 26 \\
\hline Introducing a compulsory subject "environmental protection" in all schools & 22 & 34 & 14 \\
\hline $\begin{array}{l}\text { Compulsory introduction of the "environmental protection" course to all fields of } \\
\text { study of tertiary education }\end{array}$ & 26 & 22 & 16 \\
\hline Tighter controls at workplaces causing potential contamination & 24 & 36 & 32 \\
\hline $\begin{array}{l}\text { Creation of a television program telling the truth and showing the true direction } \\
\text { in which the world is moving }\end{array}$ & 48 & 46 & 44 \\
\hline $\begin{array}{l}\text { Distribution of free books in the commune referring to ecological problems and } \\
\text { the current state of the environment containing proposals to solve the problem }\end{array}$ & 46 & 40 & 32 \\
\hline All of the above I consider to be important and effective & 36 & 22 & 20 \\
\hline
\end{tabular}

* Multiple choice

Source: own research

environment, and only $12 \%$ of them believed that warnings were enough (Table 12).

The students of the PSaR Faculty showed lower ecological awareness. Only 60\% of them admitted that each of us is responsible for the state of the environment (Fig. 5) and more than half (58\%) indicated that a reprimand would be a sufficient punishment for the environmental devastation (Table 12).

When asked: "Do you think that the University has presented you well enough about the functioning of the environment?", the surveyed students of Social Prevention and Resocialization (60\%), and Logistics (46\%) admitted that they did not have many classes of this type, while $92 \%$ of the students in the field of Environmental
Protection gained knowledge in this field at the university (Table 13).

The analysis of the results of the last assumption suggests that although some of the respondents did not gain sufficient environmental knowledge and that concerning sustainable development, they believe that it is worth changing through urgent education in this field (Table 14).

\section{Discussion}

In 2017, 30 years had passed since the Brundtland Report "Our common future" had been published. The concept of sustainable development introduced in it is defined as... "a development that meets the present needs without depriving future generations of the possibility of satisfying their needs". Attention was drawn to the 


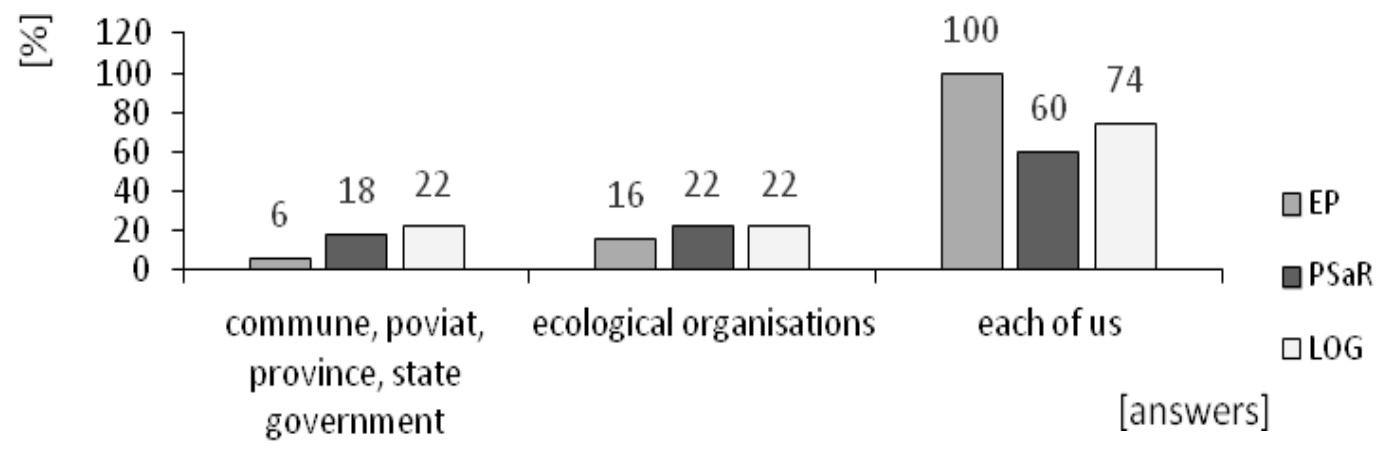

Fig. 5. Responsibility for the state of the environment [\%"], *multiple choice Source: own research

Table 12. Opinions on tightening penalties for the devastation of the environment, fauna and flora

\begin{tabular}{lcccc}
\hline \multicolumn{1}{c}{ Answers of respondents [\%] } & EP & PSaR & LOG \\
\hline Yes, punishment should be severe! & 88 & 44 & 32 \\
\hline Reprimands will suffice & 12 & 58 & 48 \\
\hline I am not really interested in it & 0 & 8 & 10 \\
\hline
\end{tabular}

Source: own research

Table 13. Evaluation of the presentation of the environmental functioning mechanism and the issues of sustainable development by the university

\begin{tabular}{lcccc}
\hline \multicolumn{1}{c}{ Answers of respondents [\%] } & EP & PSaR & LOG \\
\hline Yes, I gained a lot of knowledge on that & 92 & 4 & 2 \\
\hline I did not quite understand the problem & 0 & 36 & 42 \\
\hline I had this sort of classes but I was not interested & 8 & 0 & 10 \\
\hline There were not many classes of this type & 0 & 60 & 46 \\
\hline
\end{tabular}

Source: own research

Table 14. Assessment of the urgency of education for sustainable development taking into account improvement of the quality of human life

\begin{tabular}{lccc}
\hline \multicolumn{1}{c}{ Answers of respondents [\%] } & EP & PSaR & LOG \\
\hline Definitely yes & 64 & 4 & 14 \\
\hline Rather yes, it is worth trying & 36 & 78 & 72 \\
\hline Rather not & - & 18 & 10 \\
\hline No, there are more important problems that need to be dealt with & - & - & 4 \\
\hline
\end{tabular}

Source: own research

interdependence of the three dimensions of building the future: economic, social and environmental and the resulting need to integrate activities in these areas. It is very difficult, but sustainable development is now a desirable paradigm of development in the global concept, as evidenced for example by the Agenda 2030 adopted in 2015 and United Nations' 17 goals for sustainable development (Transforming our world...).

Implementation of sustainable development is binding in Poland in accordance 
with the Constitution of the Republic of Poland (1997); it should be urgently introduced into the practice of everyday life of both an individual consumer - a citizen $(\mathrm{CCN})$ as well as in the everyday practice of enterprises and companies realising the ethics of responsible business (Leoński 2016).

Sustainable development applies to all areas of life, technology and politics and therefore should be accepted in the whole diversity of human activities, at all levels of social organization. How to achieve it quickly and effectively? It seems that in addition to passing the knowledge about sustainable development conditionings, it is urgent to recognize and introduce methods of effective educational impact based on building ethical principles adequate to today's needs of Man and nature coexistence. The expansion of the moral basis of behaviour in this area has the potential to integrate people around the values that are important for efficient social functioning.

The research results presented in the study indicate that education for sustainable development is not carried out equally in all universities. It is often underestimated, although the media clearly emphasize the need to solve current problems in such a way as to minimize the negative effects of the decisions made in the economic, social and natural dimensions of life. All these planes are equally important for creating welfare of the human species. It must be emphasized at every opportunity that knowledge about sustainable development must not be shallow and short-lived but should result from deeply rooted ethical principles of the ecological culture.

The described research indicates differences in the perception of the world between Logistics and Social Prevention and Resocialization students, and those studying Environmental Protection. Their answers repeatedly differed in the level of understanding the human bond with ecosystems and acceptance of the rank of this relationship.
Most of the surveyed students recognized violence in the environment and knew at least one or a few people who experienced it. Almost all respondents have never heard about the existence of the term "ecological violence", although they intuitively chose correctly from the proposed definitions suggested by the authors. In earlier studies (Kostecka et al. 2012), which were carried out in Rzeszow on randomly selected adult citizens, the question "Is there a concept of ecological violence?", $78 \%$ of respondents associated it with excessive use of resources.

So what should be done to combat "ecological violence" - understanding sus tainable development and environmental protection? The thesis was positively verified that the students see the need for social rehabilitation of people who commit ecological violence and that they see the need to act responsibly in the environment. A particularly large group of respondents among students of Environmental Protection were of the opinion that everyone who contributes to the deterioration of the state of the environment should undergo a rehabilitation process and intensive education can help here. Understanding the problem more broadly, it may be worth a proposition to promote the term "violence" also in relation to environmental resources.

The authors of the study hope that although they found shortcomings in the knowledge of the issue, the survey carried out an educational role. Answering every question, the respondent had to think about and analyse his knowledge in the presented field. Therefore, one can hope that the questionnaire will remain in the memory and may even encourage the cognition of the issue of ecological violence.

According to Nowak (2015), adopting new perspectives is one of the cognitive abilities developing in the course of ontogenesis. As never before, the society of Homo sapiens needs flexible people with interactive minds, which does not mean opening up to the expansion of others, but on the contrary, it can strengthen the quality of interpersonal 
relationships in seeking mutual understanding and openness to others while determining the survival strategy of the species in the destroyed nature.

It seems that the concept of "ecological violence" has a chance to mobilize a human conscience for reflection and development, and this is a reliable (though not final) source of our beliefs about what we should do. The complicated nature of this issue is also being considered by Rutkowski (2015).

The 3oth anniversary of the Bruntland Report is an opportunity to summarize the directions of the research on sustainable development from the theoretical perspective and from the point of view of various fields of science and to evaluate how it looks in practice to strive for balancing these three dimensions of life, namely the economic, social and environmental. It is also a good opportunity to debate about the place of ethics in these three dimensions of reality and also to consider an urgent need to update the ethical assumptions to build strategies for Homo sapiens to survive in the disappearing or very rapidly changing nature of ecosystems. It seems that the introduction of the term "ecological violence" to be the base of ethical issues will deepen the influence of ethics on the perception of the world by both an individual and a global human, urgently in need of changing the perspective of its relationship with nature.

Often, we do not realize how important relationships are in life, with nature, other people or with ourselves. One should therefore consider what is building and what is killing relations. According to Glasser (2008), interpersonal relations are built by support, encouragement, friendliness, empathy and care. What kills relationships is complaining, blaming, nagging and even applying penalties and rewards, because it is a form of control. In building relationships with the environment, there is also a need for openness, care, responsibility, not devastation, exploitation or greed.

Human subjectivity and self are complex temporal and social phenomena. It is worth adding the concept of ecological violence to the considerations of the human mind, with the hope that it will evolve along with other foundations of moral action, accompanied by responsibility, action for the good of others and empathy.

\section{Summary}

In search of effective education and implementation activities for broadly defined sustainable development, it is also worth presenting, examining and refining the term "ecological violence". The current publication touches on the above issue and is a preliminary consideration in this respect. The authors hope that it will provoke them and potential readers for a deeper analysis of the possible meaning of the term "violence" also in relation to environmental resources. The presented research was of preliminary character setting the findings for a deeper analysis in the future.

\section{References}

Cavender-Bares J., Balvanera P., King E., Polasky S., 2015, Ecosystem service trade-offs across global contexts and scales. Ecology and Society, 20(1), 22.

Glasser W., 2008, Every student can succeed. Chatsworth, CA, William Glasser, 3-15.

Guide to the Millenium Assessment Reports, 2015, Millenium Ecosystem Assessment.

Konstytucja Rzeczypospolitej Polskiej, 1997, Dz.U. $1997 \mathrm{nr} 78$ poz. 483. http://prawo.sejm.gov.pl/isap. nsf/DocDetails.xsp?id= WDU19970780483. [online] [5.02.2018].

Knutelski S., 2018, Różnorodność biotyczna dobrostanem ludzkości, Polish Journal for Sustainable Development, 22(1), 27-38.

Kostecka J., 2009, Dekada edukacji dla zrównoważonego rozwoju - wizja, cel, strategia. Problemy ekorozwoju, 4, 101-106.

Kostecka J., 2010, Edukacyjne znaczenie pojęcia świadczenie ekosystemów dla ochrony awifauny miast. Inżynieria ekologiczna, 22, 34-42.

Kostecka J., Mazur-Pączka A., Podolak-Machowska A., Dunin-Mugler C., 2012, Stosunek do wybranych akcentów różnorodności biologicznej wyktadnia szans na wprowadzenie pojęcia retardacja 
przeksztatcania zasobów. Zesz. Nauk. Płd.-Wsch. Oddziału PTIE i PTG, 15, 53-61.

Kostecka J., 2013a, Retardacja tempa życia i przeksztatcania zasób przyrody - wybrane implikacje obywatelskie. Inżynieria Ekologiczna, 34, 38-52.

Kostecka J., 2013b, Self evaluation on the way to retardation of pace of life and resources transformation. Problems of Sustainable Development, 8, (2), 93--102, http://ekorozwoj.pol.lublin.pl/no16/l. pdf [online] [5.17.2018].

Kostecka J., Mazur-Pączka A., Jasińska T., Batóg K., 2013, Pojęcie „świadczenia ekosystemowe” $i$ jego rola w edukacji dla zrównoważonego rozwoju (na przykładzie bzu czarnego Sambucus nigra L.). Inżynieria i Ochrona Środowiska, 15(4), 405-417.

Leoński W., 2016, Kodeks etyczny jako instrument społecznej odpowiedzialności biznesu. Zeszyty Naukowe Politechniki Częstochowskiej. Zarządzanie. 22. 257-263. http://www.zim.pcz.pl/znwz [online] [5.06.2018].
Nowak E., 2015, Poznajac innego: perspektywizm społeczny i jego znaczenie w etyce. Etyka 51, 85-103.

Popkiewicz M., 2015, Świat na rozdrożu. Wydawnictwo Sonia Draga Sp. z o.o.

Rutkowski M., 2015, O postępowaniu pod wptywem sumienia. Etyka 50, 2015, 115-151.

Wilson E.O., 2016, Half-Earth: Our Planet's Fight for Live. Liveright Publishing Corporation. New York- London.

(Web-01) CCN. The Consumer Citizenship Network., 2006, Retrieved from www.eesc.europa. eu/sites/ default/files/resources/docs/pp_thoresen.pdf.

(Web-02) Transforming our world: The 2030 Agenda for sustainable development. 2015. A/RES/70/1. United Nations. https://sustainabledevelopment.un.org/content/documents/21252030\%20 Agenda\%2 ofor\%2oSustainable\%2oDevelopment\%20web.pdf [5.06.2018].

\section{Refleksja nad edukacją na rzecz zrównoważonego rozwoju na przestrzeni 30 lat od opublikowania Raportu Brundtland}

\section{Streszczenie}

Celem podjętych badań było poznanie opinii młodych ludzi na temat zrównoważonego rozwoju. Przedstawienie tych opinii uznano za istotne dla oceny stanu wdrażania zrównoważonego rozwoju - 30 lat po opublikowaniu Raportu Bruntland. Zidentyfikowano również zjawisko „przemocy ekologicznej” oraz opinie na temat kierunków działań przeciwko niej. Zdaniem autorów koncepcja ta powinna zostać uwzględniona, w etycznych podstawach ludzkich zachowań w XXI wieku. Badanie zostały przeprowadzone w 2017 r. wśród studentów Uniwersytetu Rzeszowskiego na Wydziale Biologiczno-Rolniczym oraz Pedagogicznym, a także Wydziale Zarządzania Politechniki Rzeszowskiej. Dla osiągnięcia celu zastosowano metodę badania diagnostycznego z wykorzystaniem kwestionariusza. Otrzymane wyniki wskazują, że edukacja na rzecz zrównoważonego rozwoju nie jest prowadzona jednakowo we wszystkich instytucjach uniwersyteckich. Edukacja ta jest niedoceniana, mimo iż media wyraźnie podkreślają jej znaczenie. Wyniki pracy mogą wskazywać kierunki działań niezbędnych w edukacji dla zrównoważonego rozwoju w XXI wieku. Dla skutecznej edukacji i wdrożenia szeroko pojętego zrównoważonego rozwoju warto przedstawić, przeanalizować i dopracować termin "przemoc ekologiczna". Niniejsza publikacja stanowi wstępną analizę powyższego problemu. Autorzy mają nadzieję, że przyczyni się to do głębszej analizy możliwego znaczenia terminu "przemoc” również w odniesieniu do zasobów środowiska.

\section{Słowa kluczowe}

edukacja, zrównoważony rozwój, przemoc ekologiczna 